\title{
Assessment of the Effect of different Levels of Nitrogen and Plant Spacing on Growth, Yield and Quality of Onion (Allium cepa L.) cv. Agrifound Light Red
}

\author{
Shilpa Kumari ${ }^{1}$ and Rahul Kumar ${ }^{2 *}$
}

${ }^{1}$ Division of Vegetable Science, S. K. Nagar, S. D. Agricultural University, Sardarkrushinagar, Banaskantha, Gujarat (385 506), India ${ }^{2}$ Division of Vegetable Science, Indian Agricultural Research Institute, Pusa, New Delhi (110 012), India

\section{Corresponding Author}

Rahul Kumar

e-mail: rahulvegiari@gmail.com

\author{
Article History \\ Manuscript No. AR1800e \\ Received in $28^{\text {th }}$ February, 2017 \\ Received in revised form $16^{\text {th }}$ May, 2017 \\ Accepted in final form $7^{\text {th }}$ June, 2017
}

\begin{abstract}
A field experiment was conducted during the year 2014-15 in order to study the effect of different levels of nitrogen and plant spacing on growth, yield and quality of onion (Allium cepa L.) cv. Agrifound Light Red. The two factor experiment was laid out in a randomized block design (RBD) with three replications. The results demonstrated that plant spacing had significant effects on growth, yield components and yield of onion. Different fertilizers combination exhibited significant variation in respect of individual bulb weight, bulb diameter and yield. The results revealed that the maximum plant height, maximum number of leaves and maximum girth thickness at 45 and 90 days after transplanting (DAT) as well as quality traits like bolting percentage, maximum bulb diameter, minimum days taken for maturity, maximum average weight of bulb and maximum total soluble solids was recorded with treatment $150 \mathrm{~kg} \mathrm{~N} \mathrm{ha}^{-1}$. Onion cultivar Agrifound Light Red spaced at treatment $\left(15 \times 10 \mathrm{~cm}^{2}\right)$ recorded the maximum plant height, number of leaves, girth thickness, bolting percentage and maximum yield per plot as well as per hactare at 45,90 days after transplanting. While at the same treatment onion cultivar Agrifound Light Red recorded minimum days for maturity (120.56) with treatment $15 \times 10 \mathrm{~cm}^{2}$. The results indicated that, among the sixteen treatment combinations $n_{3} m_{2} s_{2}$ recorded maximum gross Cost : Benefit Ratio $(1: 5.67)$. Thus, from the present investigation it can be concluded that for optimum growth, higher yield and better quality of onion, the application of $150 \mathrm{~kg} \mathrm{~N} \mathrm{ha}^{-1}$ and $15 \times 10 \mathrm{~cm}^{2}$ plant spacing is very useful.
\end{abstract}

Keywords: Onion, RBD, girth thickness, bulb diameter, TSS

\section{Introduction}

Onion (Allium cepa) is an important bulb crop, belonging to the family Alliaceae. It is one of the most important and popular spice crops in India as well as in the world. The crop was originated somewhere between western China and deserts lying east of the Caspian Sea (Jones and Mann, 1963). India is prominent in the production and export of onion in the world. Onion is being grown in area of 9.03 mha with total bulb production of $14.40 \mathrm{mt}$ (Anonymous, 2014-2015). In world, India ranks $2^{\text {nd }}$ in area and $5^{\text {th }}$ in production of onion. Optimum plant density is a pre-requisite for maximum yield. Increasing plant density results in suppression of biological yield of individual plant, but production increases on per plant basis of unit land area. Plant density greatly influenced quality, texture, taste and yield of onion (Dawar et al., 2007). Khan and coworker (2002) reported a significant effect of all the growth and yield components of onion and larger percentage of small and medium bulbs were obtained in the narrowest spacing. Nitrogen is essential for growth and yield of onion but application of high rates cause delay in bulb maturity and encourage bolting (flowering), which is an undesirable characteristics (Aliyu et al., 2007). Much attention should be given to fertilizer management of onion plant when compared to other crops, since onion possesses shallow root system and faces problem in the absorption of immobile nutrients in the soil for attaining maximum yield (Halvorson et al., 2008). The optimum use of spacing or plant population has dual advantages. It also avoids strong competition between plants for growth factor such as water, nutrient and light. Conversely, optimum plant population enables efficient use of available crop land without wastage (Zubelidia and Gases, 1977). But very little work has so far been done in respect of spacing and organic-inorganic fertilizer combination under the agro-climatic condition of Gujrat. Therefore, the present investigation has been carried out with the following objectives: To find out the optimum plant spacing and level of nitrogen with respect to growth and yield of onion.

\section{Materials and Methods}

The experiment was conducted at Horticulture Instructional Farm, College of Horticulture, S. D. Agricultural University, 
Sardarkrushinagar, Dist. Banaskantha, Gujarat in the year 2014-15 to study the effect of different levels of nitrogen and plant spacing on growth, yield and quality of onion (Allium cepa L.) cv. Agrifound Light Red. The experimental area was medium high land and the soil was sandy to clay loam. Onion cultivar Agrifound Light Red a high yielding variety was considered for this study as a test material. Five tones of vermicompost, $50 \mathrm{~kg} \mathrm{P}_{2} \mathrm{O}_{5}$ and $50 \mathrm{~kg} \mathrm{~K}_{2} \mathrm{O}$ in the form of single super phosphate and murate of potash applied at the time of soil preparation. Nitrogen was applied in the form of urea as per treatment. The two factor experiment was laid out in a randomized block design (RBD). The whole field was first divided into 4 blocks each containing 4 plots. 16 combination of treatments (Table 1 and 2) were formed with four treatments of levels of nitrogens $n_{0}\left(0 \mathrm{~kg} \mathrm{ha}^{-1}\right), \mathrm{n}_{1}$ $\left(100 \mathrm{~kg} \mathrm{ha}^{-1}\right), \mathrm{n}_{2}\left(125 \mathrm{~kg} \mathrm{ha}^{-1}\right)$ and $\mathrm{n}_{3}\left(150 \mathrm{~kg} \mathrm{ha}^{-1}\right)$ respectively and for plant spacing two treatment were formed namely $\mathrm{s}_{1}$ $\left(10 \times 10 \mathrm{~cm}^{2}\right)$ and $s_{2}\left(15 \times 10 \mathrm{~cm}^{2}\right)$. The following parameters were studied: Growth parameter viz. plant height $(\mathrm{cm})$; number of leaves plant ${ }^{-1}$; neck thickness of plant $(\mathrm{cm})$; days taken for maturity; bolting percentage (\%) and Yield and Yield Attributes traits viz. average weight of bulb (g); yield of bulb per plot (kg); yield of bulb ha-1 (quintal); diameter of bulb $(\mathrm{cm})$; neck thickness after curing $(\mathrm{cm})$ and total soluble solids percentage (TSS \%). The data collected were analyzed using Fisher's analysis of variance technique and differences among the various treatments were determined by using least significant difference test at 5\% probability level (Steel and Torrie, 1984). The cost of cultivation was worked out by considering the expenses incurred for cultural operations from preparation tillage to harvesting of including the cost of inputs viz. seeds, manures, fertilizers, insecticides and irrigation etc. under each treatment. The cost of cultivation was then deducted from the gross realization to work out the net profit under each treatment. The cost benefit ratio (CBR) was calculated on the basis of the formula as CBR=Total realization (₹ ha-1)/ Total expenditure (₹ ha-1)

\section{Results and Discussion}

Table 1 and 2 indicates observations for yield and quality parameters respectively. Data revealed the effectiveness of different levels of nitrogen in comparison to control treatment at different stages of plant height, no of leaves per plant and girth thickness. During the investigation the trends of growth was more or less similar at different stages i.e., 45 and 90 days after transplanting. Treatment $n_{3}\left(150 \mathrm{~kg} \mathrm{~N} \mathrm{ha}^{-1}\right)$ was found to be more effective one and significantly maximum plant height i.e. $36.00 \mathrm{~cm}$ and $71.67 \mathrm{~cm}$ were recorded at 45 days and 90 days after transplanting, respectively. Treatment $\mathrm{n}_{0}$ (control) was recorded minimum plant height i.e. $26.50 \mathrm{~cm}$ and $47.20 \mathrm{~cm}$ in comparison to all other levels of nitrogen. These findings are in close accordance with the findings of Prathana et al. (2002) in onion, Yadav (2003) in garlic. Influences of plant spacing with respect to plant height were found significant. Treatment $\left(15 \times 10 \mathrm{~cm}^{2}\right.$ spacing) was found significantly superior than treatment $10 \times 10 \mathrm{~cm}^{2}$. Significantly maximum plant height $32.09 \mathrm{~cm}$ and $62.44 \mathrm{~cm}$ were recorded with treatment $15 \times 10 \mathrm{~cm}^{2}$ at 45 days and 90 days after transplanting, respectively and minimum plant height $30.89 \mathrm{~cm}$ and $60.31 \mathrm{~cm}$ were recorded with $10 \times 10 \mathrm{~cm}^{2}$ treatment. These results are in conformity with the findings of Akoun J. (2005) in onion. While for number of leaves

Table 1: Effect of different levels of nitrogen and plant spacing on plant height $(\mathrm{cm})$, number of leaves plant ${ }^{-1}$, neck thickness (cm) bolting \% and days taken for maturity

\begin{tabular}{|c|c|c|c|c|c|c|c|c|}
\hline \multirow[t]{2}{*}{ Treatment } & \multicolumn{2}{|c|}{ Plant height $(\mathrm{cm})$} & \multicolumn{2}{|c|}{ No. of leaves } & \multicolumn{2}{|c|}{ Neck thickness $(\mathrm{cm})$} & \multirow[t]{2}{*}{ Bolting \% } & \multirow[t]{2}{*}{ Days taken for maturity } \\
\hline & 45 DAT & 90 DAT & 45 DAT & 90 DAT & 45 DAT & 90 DAT & & \\
\hline \multicolumn{9}{|c|}{ Levels of nitrogen (n) } \\
\hline $\mathrm{n}_{0}\left(0 \mathrm{~kg} \mathrm{ha}^{-1}\right)$ & 26.50 & 47.20 & 4.60 & 7.13 & 0.52 & 1.46 & 5.81 & 128.13 \\
\hline $\mathrm{n}_{1}\left(100 \mathrm{~kg} \mathrm{ha}^{-1}\right)$ & 30.51 & 60.06 & 5.14 & 7.98 & 0.64 & 1.56 & 7.38 & 123.27 \\
\hline $\mathrm{n}_{2}\left(125 \mathrm{~kg} \mathrm{ha}^{-1}\right)$ & 32.94 & 66.57 & 5.46 & 8.32 & 0.70 & 1.65 & 7.58 & 118.87 \\
\hline $\mathrm{n}_{3}\left(150 \mathrm{~kg} \mathrm{ha}^{-1}\right)$ & 36.00 & 71.67 & 5.71 & 8.70 & 0.77 & 1.80 & 8.33 & 114.35 \\
\hline SEm \pm & 0.50 & 1.02 & 0.08 & 0.14 & 0.01 & 0.03 & 0.16 & 0.53 \\
\hline $\mathrm{CD}(p=0.05)$ & 1.45 & 2.96 & 0.24 & 0.41 & 0.04 & 0.07 & 0.46 & 1.54 \\
\hline \multicolumn{9}{|l|}{ Spacing (s) } \\
\hline $\mathrm{s}_{1}\left(10 \times 10 \mathrm{~cm}^{2}\right)$ & 30.89 & 60.31 & 5.14 & 7.88 & 0.62 & 1.58 & 7.10 & 121.74 \\
\hline $\mathrm{s}_{2}\left(15 \times 10 \mathrm{~cm}^{2}\right)$ & 32.09 & 62.44 & 5.32 & 8.18 & 0.67 & 1.64 & 7.44 & 120.56 \\
\hline SEm \pm & 0.36 & 0.72 & 0.06 & 0.10 & 0.01 & 0.02 & 0.11 & 0.38 \\
\hline $\operatorname{CD}(p=0.05)$ & 1.03 & 2.09 & 0.17 & 0.29 & 0.03 & 0.05 & 0.32 & 1.09 \\
\hline \multicolumn{9}{|l|}{ Interaction } \\
\hline $\mathrm{n} \times \mathrm{s}$ & N.S. & N.S. & N.S. & N.S. & N.S. & N.S. & N.S. & N.S. \\
\hline
\end{tabular}


Table 2: Effect of different levels of nitrogen and plant spacing on average weight of bulb $(\mathrm{g})$, diameter of bulb $(\mathrm{cm})$, yield of bulb plot ${ }^{-1}(\mathrm{~kg})$, Yield of bulb ha ${ }^{-1}(\mathrm{q})$ and Total soluble solid (TSS)

\begin{tabular}{|c|c|c|c|c|c|}
\hline Treatment & AWB & DB & YBP & YBH & TSS \\
\hline \multicolumn{6}{|c|}{ Levels of nitrogen (n) } \\
\hline $\mathrm{n}_{0}\left(0 \mathrm{~kg} \mathrm{ha}^{-1}\right)$ & 66.88 & 4.63 & 8.38 & 304.82 & 12.46 \\
\hline $\mathrm{n}_{1}\left(100 \mathrm{~kg} \mathrm{ha}^{-1}\right)$ & 90.73 & 6.02 & 12.13 & 441.20 & 12.71 \\
\hline $\mathrm{n}_{2}\left(125 \mathrm{~kg} \mathrm{ha}^{-1}\right)$ & 97.48 & 7.11 & 14.83 & 539.98 & 12.83 \\
\hline $\mathrm{n}_{3}\left(150 \mathrm{~kg} \mathrm{ha}^{-1}\right)$ & 109.78 & 7.88 & 18.71 & 679.43 & 13.07 \\
\hline SEm \pm & 1.37 & 0.08 & 0.27 & 10.04 & 0.06 \\
\hline $\mathrm{CD}(p=0.05)$ & 3.97 & 0.24 & 0.79 & 28.98 & 0.19 \\
\hline \multicolumn{6}{|l|}{ Spacing (s) } \\
\hline$s_{1}\left(10 \times 10 \mathrm{~cm}^{2}\right)$ & 87.57 & 6.20 & 12.92 & 460.77 & 12.70 \\
\hline $\mathrm{s}_{2}\left(15 \times 10 \mathrm{~cm}^{2}\right)$ & 94.87 & 6.61 & 14.11 & 521.94 & 12.84 \\
\hline SEm \pm & 0.97 & 0.06 & 0.19 & 7.10 & 0.05 \\
\hline$C D(p=0.05)$ & 2.81 & 0.17 & 0.56 & 20.49 & 0.13 \\
\hline
\end{tabular}

AWB: Average weight of bulb (g); DB: Diameter of bulb (cm); YBP: Yield of bulb plot $^{-1}(\mathrm{~kg})$; YBH: Yield of bulb ha- ${ }^{-1}(\mathrm{q}) ;$ TSS: Total soluble solid

per plant treatment $\mathrm{n}_{3}$ was found significantly superior and recorded 5.71 and 8.70 leaves per plant at 45 and 90 days after transplanting and minimum 4.60 and 7.13 number of leaves were recorded with control treatment at 45 and 90 days after transplanting, respectively. The treatments $n_{2}$ $\left(125 \mathrm{~kg} \mathrm{ha}^{-1}\right)$ was found significantly at par with treatment $\mathrm{n}_{3}$ at 90 days after transplanting. The increase in number of leaves might be due to the fact that nitrogen synthesized into amino acids and proteins which allowed the plant to grow faster. Nitrogen is a builder of protein and it forms the main constituents of protoplasm in plants. When nitrogen supply in adequate quantity, create the favorable condition for growth. Similar results were obtained by Prathana et al. (2002); Yadav et al. (2007) in garlic. Influences of plant spacing with respect to number of leaves plant ${ }^{-1}$ were found significant variation. Maximum leaves plant ${ }^{-1}$ was recorded with treatment $\mathrm{s}_{2}\left(15 \times 10 \mathrm{~cm}^{2}\right)$ i.e. 5.32 and 8.18 at 45 and 90 days after transplanting. Maximum number of leaves is due to better availability of plant nutrients and sunlight exposure under wider spacing. This is similar to findings of Singh and Sachan (1999), Panda and Mohanty (2001) in onion and Akoun J. (2005). The interaction effect between $n$ and $s$ was found not significant variation at different stages of plant growth. Significantly maximum plant girth thickness was recorded with treatment $n_{3}\left(150 \mathrm{~kg} \mathrm{ha}^{-1}\right)$ i.e., $0.77 \mathrm{~cm}, 1.80 \mathrm{~cm}$ and $0.39 \mathrm{~cm}$ at 45, 90 days after transplanting and after curing, respectively. Minimum girth thickness i.e., $0.52 \mathrm{~cm}, 1.46 \mathrm{~cm}$ and $0.25 \mathrm{~cm}$ were observed with control treatment at 45,90 days after transplanting and after curing, respectively. These findings are confirming the results by earlier works by Prathana et al. (2002); Yadav (2003) in garlic and Yadav et al. (2007) in garlic. Influences of plant spacing with respect to plant girth thickness were found significant. Maximum girth thickness i.e., 0.67 $\mathrm{cm}, 1.64 \mathrm{~cm}$ and $0.33 \mathrm{~cm}$ were recorded with treatment $\mathrm{s}_{2}$ $\left(15 \times 10 \mathrm{~cm}^{2}\right) 45,90$ days after transplanting and after curing, respectively and minimum girth thickness $0.62 \mathrm{~cm}, 1.58 \mathrm{~cm}$ and $0.30 \mathrm{~cm}$ was recorded with $\mathrm{s}_{1}$ treatment. This is similar to findings of Panda and Mohanty (2001); Akoun J. (2005).

Influences of different levels of nitrogen and plant spacing on bolting percentage maturity of bulb summarized in Table 1. The influences of different levels of nitrogen on bolting percent were found significant variation. Maximum bolting percent (8.33) was obtained under treatment $n_{3}(150 \mathrm{~kg} \mathrm{~N}$ $\mathrm{ha}^{-1}$ ) and minimum bolting percent (5.81) were recorded with control treatment. These findings are confirm the results by earlier works like Kumar et al. (1998), Yadav (2003); Yadav et al. (2007) in garlic. Influence of plant spacing on bolting percent was found significant variation. Maximum bolting percent 7.44 was recorded with $\mathrm{s}_{2}\left(15 \times 10 \mathrm{~cm}^{2}\right)$ treatment and minimum 7.10 was recorded with $\mathrm{s}_{1}$ treatment. This is similar to findings of Panda and Mohanty (2001); Akoun J. (2005).

In case of yield and yield attributing traits like average weight of the bulb, days taken for maturity of bulb, diameter of bulb, yield of bulb plot ${ }^{-1}(\mathrm{~kg})$, yield of bulb ha- ${ }^{-1}(\mathrm{q})$ and total soluble solids (TSS) which are yield and yield attributing traits was influenced by different levels of nitrogen, methods of application and plant spacing are summarized in Table 1 and 2. Days taken for maturity of bulb as influenced by nitrogen showed marked variation and found significant early maturity due to $n_{3}$ treatment. Treatment $n_{3}\left(150 \mathrm{~kg} \mathrm{ha}^{-1}\right)$ was found significantly superior with respect to minimum days taken for maturity ( 114.35 days) and maximum days taken for maturity (128.13 days) was recorded with treatment $n_{0}\left(0 \mathrm{~kg} \mathrm{ha}^{-1}\right)$. Similar results were also reported by Kumar et al. (1998), Prathana et al. (2002); Yadav (2003); Yadav et al. (2007) in garlic. Influence of plant spacing with respect to days taken for maturity was found significant variation. Minimum days taken for maturity ( 120.56 days) was recorded with treatment $\mathrm{S}_{2}$ and maximum days taken for maturity was recorded with treatment $\mathrm{s}_{1}\left(10 \times 10 \mathrm{~cm}^{2}\right)$ i.e., (121.74 days). This is similar to findings of Panda and Mohanty (2001); Akoun J. (2005). The data presented in table showed that the application of nitrogen produced bulb having more weight than the without nitrogen treatment. Treatment $n_{3}$ produced significantly maximum weight of bulb as compared to all other levels of nitrogen and control treatment, respectively. The maximum bulb weight $109.78 \mathrm{~g}$ was recorded with treatment $\mathrm{n}_{3}(150$ $\mathrm{kg} \mathrm{ha}^{-1}$ ) and minimum $66.88 \mathrm{~g}$ was obtained under control n0 $\left(0 \mathrm{~kg} \mathrm{ha}^{-1}\right)$ treatment. Nitrogen application at $150 \mathrm{~kg} \mathrm{~N}$ $\mathrm{ha}^{-1}$ resulted in higher yield than other levels tested. Similar results have been reported by Diaz-Perez et al. (2003); Singh et al. (2004); Zaman et al (2011); Alassaf (2013). Influence of plant spacing with respect to average weight of bulb was 
found significant variation. Maximum $94.87 \mathrm{~g}$ was recorded with $\mathrm{s}_{2}$ treatment in comparison to minimum average weight of bulb $87.57 \mathrm{~g}$ recorded with treatment $\mathrm{S}_{1}$. The reduced weight of bulb in closer spacing might be due to decreased in plant height and number of leaves. This is similar to findings of Sharma (1998); Nandal et al. (2008) in garlic. The combined effect between nitrogen and plant spacing on average weight of bulb was found significant. Treatment combination $\mathrm{N}_{3} \mathrm{~S}_{2}\left(150 \mathrm{~kg} \mathrm{ha}^{-1}\right.$ of nitrogen and $15 \times 10 \mathrm{~cm}^{2}$ spacing between bulb) observed significantly superior over all other treatment combination. Maximum bulb weight was recorded with $n_{3} s_{2}(116.33 \mathrm{~g})$ and minimum was observed under treatment $\mathrm{N}_{0} \mathrm{~S}_{1}(66.17 \mathrm{~g})$. The maximum bulb diameter was recorded $(7.88 \mathrm{~cm})$ with treatment $\mathrm{n}_{3}$ and minimum bulb diameter was recorded $(4.63 \mathrm{~cm})$ with $\mathrm{n}_{0}$ treatment. These findings are in close accordance with the findings of Kumar et al. (1998); Prathana et al. (2002) but contrast to Jilani et al. (2010) who were reported that decreasing the plant spacing increases in total yield of onion. Influence of plant spacing with respect to diameter of bulb was found significant variation. Maximum bulb diameter $6.61 \mathrm{~cm}$ was recorded with $\mathrm{s}_{2}$ treatment in comparison to minimum bulb diameter 6.20 $\mathrm{cm}$ recorded with treatment $\mathrm{s}_{1}$. The maximum bulb diameter was recorded in wider spacing. This might be due to better nutrition available to the individual plant under wider spacing. This is similar to findings of Sharma (1992) in and Katon et al. (2002). Maximum onion yield plot ${ }^{-1}$ was obtained (18.71 $\mathrm{kg}$ ) under treatment $\mathrm{n}_{3}$ and minimum yield per plot i.e., 8.38 $\mathrm{kg}$ recorded with treatment $\mathrm{n}_{0}$. The increase in yield due to higher levels of nitrogen may be explained on the basis that net assimilation was accelerate by the increase chlorophyll content of the nitrogen fed plant and absorbed nitrogen helped in the preservation of more food reserves due to higher photosynthetic activity. The similar results were obtained by Singh and Singh (2000); Aliyu et al. (2007); Khan et al. (2002). In case of plant spacing treatment $\mathrm{s}_{2}$ was found significantly superior than $s_{1}$ treatment. Significantly maximum onion yield $\operatorname{plot}^{-1}(14.11 \mathrm{~kg})$ was recorded with treatment $\mathrm{s}_{2}$ and minimum $(12.92 \mathrm{~kg})$ was observed under $\mathrm{s}_{1}\left(10 \times 10 \mathrm{~cm}^{2}\right)$ treatment. This is similar to findings of Nandal et al. (2008) in garlic. The data pertaining to yield of onion bulb ha-1 ${ }^{-1}$ howed the effectiveness of nitrogen in increasing the yield. The data revealed that treatment $n_{3}\left(150 \mathrm{~kg} \mathrm{~N} \mathrm{ha}^{-1}\right)$. produced significantly higher yield $\left(679.43 \mathrm{q} \mathrm{ha}^{-1}\right)$ in comparison to all other treatments of nitrogen under experimentation and minimum yield (304.82 $\mathrm{q} \mathrm{ha}{ }^{-1}$ ) was recorded in treatment $\mathrm{n}_{0}\left(0 \mathrm{~kg} \mathrm{~N} \mathrm{ha}^{-1}\right)$. Increase yield ha $^{-1}$ with application of nitrogen was observed by Singh and Singh (2000) in onion, Reddy et al. (2000) in garlic and Yadav et al. (2007) in garlic. Treatment combination $n_{3} s_{2}$ and $\mathrm{n}_{3} \mathrm{~s}_{1}$ was significantly at par with respect to yield of onion bulb ha ${ }^{-1}$ in quintal. Influence of plant spacing on total soluble solids was found significant variation. Maximum total soluble solids (12.84) were recorded with $\mathrm{s}_{2}\left(15 \times 10 \mathrm{~cm}^{2}\right)$ treatment in comparison to $s_{1}\left(10 \times 10 \mathrm{~cm}^{2}\right)$ treatment $(12.70)$. This is similar to findings of Sharma (1992); Nasreen, S. et al. (2007).
Interaction of all these treatment found to be non significant for all the growth, yield as well as for the quality traits except the treatment combination $n_{3} m_{2} s_{2}$, where highest yield plot ${ }^{-1}$ $(19.93 \mathrm{~kg})$ in comparison to all other treatment combination were recorded. Treatment combination $n_{3} m_{1} s_{2}$ and $n_{3} m_{2} s_{1}$ was significantly at par with respect to yield of onion bulb per plot in $\mathrm{kg}$.

\section{Economics of Onion Cultivation under Study}

The gross realization in term of rupees ha-1 was worked out by working into consideration the prevailing market price of the onion under each treatment during the year 2014-15. Results regarding in economics i.e., cost of cultivation, gross return, net return and Cost: Benefit Ratio are presented in Table 3. The results indicated that, among the sixteen treatment combinations $n_{3} m_{2} s_{2}$ recorded maximum gross return ( $₹ 14,67,920)$, net return ( $₹ 12,47,938$ ) and Cost:Benefit Ratio (1 : 5.67). Whereas, treatment combinations $n_{0} m_{2} s_{1}$ recorded minimum in gross returns ( $₹ 5,84,520$ ), net returns (₹ 3,68,960) and Cost : Benefit Ratio (1:1.71).

\begin{tabular}{|c|c|c|c|c|c|}
\hline $\begin{array}{l}\text { Treat- } \\
\text { ments }\end{array}$ & $\begin{array}{l}\text { Yield } \\
\left(\mathrm{q} \mathrm{ha} \mathrm{h}^{-1}\right)\end{array}$ & $\begin{array}{c}\text { Gross re- } \\
\text { alization } \\
\left(₹ \mathrm{ha}^{-1}\right)\end{array}$ & $\begin{array}{l}\text { Total } \\
\text { expen- } \\
\text { diture } \\
\left(₹ \text { ha }^{-1}\right)\end{array}$ & $\begin{array}{l}\text { Net re- } \\
\text { alization } \\
\left(₹ \mathrm{ha}^{-1}\right)\end{array}$ & $\begin{array}{l}\text { Cost: } \\
\text { Benefit } \\
\text { ratio }\end{array}$ \\
\hline $\mathrm{n}_{0} \mathrm{~m}_{1} \mathrm{~s}_{1}$ & 301.94 & 603880 & 215560 & 388320 & $1: 1.81$ \\
\hline $\mathrm{n}_{0} \mathrm{~m}_{1} \mathrm{~s}_{2}$ & 311.21 & 622420 & 215560 & 406860 & $1: 1.88$ \\
\hline $\mathrm{n}_{0} \mathrm{~m}_{2} \mathrm{~s}_{1}$ & 292.26 & 584520 & 215560 & 368960 & $1: 1.7$ \\
\hline$n_{0} m_{2} s_{2}$ & 313.9 & 627800 & 215560 & 412240 & $1: 1.91$ \\
\hline$n_{1} m_{1} s_{1}$ & 440.93 & 881860 & 218514 & 663346 & $1: 3.03$ \\
\hline$n_{1} m_{1} s_{2}$ & 437.78 & 875560 & 218514 & 657046 & 1: 3.01 \\
\hline $\mathrm{n}_{1} \mathrm{~m}_{2} \mathrm{~s}_{1}$ & 409.07 & 818140 & 218514 & 599626 & $1: 2.74$ \\
\hline $\mathrm{n}_{1} \mathrm{~m}_{2} \mathrm{~s}_{2}$ & 477.03 & 954060 & 218514 & 735546 & $1: 3.36$ \\
\hline$n_{2} m_{1} s_{1}$ & 466.3 & 932600 & 219250 & 713350 & $1: 3.25$ \\
\hline $\mathrm{n}_{2} \mathrm{~m}_{1} \mathrm{~s}_{2}$ & 578.7 & 1157400 & 219250 & 938150 & $1: 4.27$ \\
\hline $\mathrm{n}_{2} \mathrm{~m}_{2} \mathrm{~s}_{1}$ & 517.27 & 1034540 & 219250 & 815290 & $1: 3.71$ \\
\hline $\mathrm{n}_{2} \mathrm{~m}_{2} \mathrm{~s}_{2}$ & 597.81 & 1195620 & 219250 & 976370 & $1: 4.45$ \\
\hline$n_{3} m_{1} s_{1}$ & 577.58 & 1155160 & 219982 & 935178 & $1: 4.25$ \\
\hline$n_{3} m_{1} s_{2}$ & 725.17 & 1450340 & 219982 & 1230358 & $1: 5.59$ \\
\hline$n_{3} m_{2} s_{1}$ & 681.01 & 1362020 & 219982 & 1142038 & $1: 5.19$ \\
\hline $\mathrm{n}_{3} \mathrm{~m}_{2} \mathrm{~s}_{2}$ & 733.96 & 1467920 & 219982 & 1247938 & $1: 5.67$ \\
\hline
\end{tabular}

Selling price of onion ₹ $20 \mathrm{~kg}^{-1}$

\section{Conclusion}

To have optimum growth higher yield and better quality of of onion cultivar agrifound light red, the application of 150 kg nitrogen ha- ${ }^{-1}$ in split i.e., $20 \%$ as basal and rest of $80 \%$ in four equal splits at $30,45,60$ and 75 days of transplanting 
and $15 \times 10 \mathrm{~cm}^{2}$ spacing is very useful.

\section{References}

Akoun, J., 2005. Effect of plant density and manure on the yield and yield components of the common onion (Allium cepa L.) var. Nsukka red. Niggerian Journal Horticultural Science 9, 43-48.

Aliyu, U., Manga Ji, M.D., Yakubu., A.I., Dikko, A.U., 2007. Correlation and path coefficient analysis for some yield related traits in onion (Allium cepa L.). Journal of Plant Science 2(3), 366-369.

Anonymous, 2014-15. Indian Horticulture Database, National Horticulture Board, Ministry of Agriculture, Government of India, New Delhi.

Dawar, N.M., Wazir, F.K., Dawar, M., Dawar, S.H., 2007. Effect of planting density on growth and yield of of onion varieties under climatic conditions of Peshawar. Sarhad Journal of Agriculture 23(4), 912-917.

Diaz-Perez, J.C., Purvis, A.C., Paulk, J.T., 2003. Bolting, yield, and bulb decay of sweet onion as affected by nitrogen fertilization. Journal American Society Horticultural Science 128, 144-149.

Halvorson, A.D., Bartolo, M.E., Reule, C.A., Berrada, A., 2008. Nitrogen effects on onion yield under drip and furrow irrigation. Agronomy Journal. 100(4), 1062-1069.

Ingle, M.B., Diware, D.V., Dod, V.N., 2000. Quality and bulb yield of garlic as influenced by planting method and spacing. Crop research (Hissar), 20(1), 160-162.

Jilani, M.S., 2004. Studies on the management strategies for bulb and Seedproduction of different cultivars of onion (Allium cepa L.). a dissertation submitted to NWFP. Agriculture University, Peshawar, Pakistan.http:// eprints.hec.gov.pk/1013/1/744.html.htm.

Jones, H.A., Mann., L.K., 1963. Onion and their allies. Leonard Hill (books) Ltd. London, 32.

Khan, H., Iqbal, M., Ghaffoor, A., Waseem, K., 2002. Effect of various plant spacing and different nitrogen levels on the growth and yield of onion (Allium cepa L.). Journal of Biological Science 2(8), 545-547.

Kumar, H., Singh, J.V., Ajay, K., Singh., M., Kumar, A., Singh, M., 1998. Studied on the influence of nitrogen on growth and yield of onion (Allium cepa L.) cv. 'Patna Red'. Indian Journal of Agriculture Research 32(2), 88-92.

Kumar, H., Singh, J.V., Ajay, K., Singh, M., Kumar, A., Singh, M., 1998. Studied the effect of spacing on growth and yield of onion (Allium cepa L.) cv. 'Patna Red'. Indian Journal of Agriculture Research 32 (2), 134-138.

Nandal, J.K., Tehlan, S.K., Gupta, V., and Singh, K., 2008. Effect of nitrogen levels and spacing on growth and yield of garlic (Allium sativum L.). Haryana journal of Horticulture
Science 37(3\&4), 375-376.

Nasreen, S., Haque, M.M., Hossain, M.A., Farid, A.T.M., 2007. Nutrient uptake and yield of onion as influenced by nitrogen andsulphur fertilization. Bangladesh Journal of Agriculture Research 32(3), 413-420.

Panda, S.C., Mohanty, B.K., 2001. Effect of plant density on the performance of multiplier onion. Orissa Journal of Horticulture 29, 110-111.

Prathana, S., Jyoti, H., Cherjan, Y.D., Sarode, P., Haldi, J., 2002. Nutrient uptake and yield of onion as influenced by fertilizer levels. Journal of Soil and Crops 11 (2), 276-277.

Reddy, G.S., Suryanarayana, K., Reddy, K.M., Reddy, K.C., 2000. Effect of different levels of nitrogen and phosphorus on yield component in garlic (Allium cepa L.). Journal Research ANGRAU 28(3), 56-59.

Sharma, D.P., 1998. Effect of age of seedling and nitrogen levels on growth and yield of onion cv. Pusa Red (Allium cepa L.). Advance Plant Science 11(1), 237-239.

Singh, R.B., Singh, S.B., 2000. Significance of nitrogen, phosphorus and potash on onion (Allium cepa L.) raised from onion sets (Bulblets). Vegetable Science, 27(1), 88-89.

Singh, S.G., Sachan, B.P., 1999. Interaction of bulb size and spacing on seed yield and yield attributing trait of onion (Allium cepa L.) cv. Kalayanpur Round Red. Scientific Horticulture 6, 125-128.

Singh, S., Yadav, P.K., Singh, B., 2004. Effect of nitrogen and potassium on growth and yield of onion (Allium cepa $\mathrm{L}$.) Cv. Pusa Red. Haryana Journal of Horticultural Science. 33(3\&4), 308-309.

Steel, R.G., Torrie., J.H., 1984. Principles and Procedures of Statistics: A Biometrical Approach, 173-91. McGraw Hill Co. New York.

Yadav, P.K., 2003. Effect of nitrogen and potassium on growth and yield of garlic (Allium sativum L.) in Western Rajasthan. Haryana Journal of Horticultural Science 32 (3/4), 290-291.

Yadav, R.S., Sammauria, R., Rathor, M.S., 2007. Effect of nitrogen and potassium on growth, yield and quality of garlic (Allium sativum L.) in light textured soil of Rajasthan. The Indian Journal of Agriculture Science, 77(3), 34-36.

Zaman, M.S., Hasham, M.A., Jahiruddin, M., Rahim, M.A., 2011. Effect of nitrogen for yield maximization of garlic in old Brahmapatra flood plain soil. Bangladesh Journal of Agriculturaln Research 36(2), 357-367.

Zubeldia., A., Gases, J.L., 1977. The effect of spacing and number of stem on the earliness and total yield of tomato cultivars. Production vegetable. 